\title{
Pruning Affects Tree Movement in Hurricane Force Wind
}

\author{
Edward F. Gilman, Forrest Masters, and Jason C. Grabosky
}

\begin{abstract}
The goal of this study was to determine how different pruning techniques affect trunk movement on live oak subjected to hurricane force winds. Tree movement in wind on nonpruned trees was compared with movement on trees with crowns thinned, reduced, or raised. Twenty trees were blown using a wind generator up to $45 \mathrm{~m} / \mathrm{s}(110 \mathrm{mph})$ maintained for $3 \mathrm{~min}$. Each tree was instrumented with three orientation sensors at set heights along the trunk to measure its deflection. Thinning or reducing crowns significantly reduced upper trunk movement at all wind speeds, whereas raising did not. Lower trunk movement was not affected by pruning type. These data indicated that foliage and branches toward the top of tree crowns were largely responsible for trunk movement in straight-line wind with those toward the bottom less important. Trees that are reduced or thinned in the manner described could receive less damage in windstorms.
\end{abstract}

Key Words. Crown raising; crown reduction; crown thinning; hurricanes; tree damage.

Homeowners perceive a high risk from trees in regions where hurricanes frequently reach shore (Peacock et al. 2005). Damage to utility lines is caused primarily by trees falling on and breaking the lines (Cook 1990). Structures positioned on properties with more trees per unit area received less damage from hurricane force winds than properties with a lower tree density; however, where there are more trees per unit area, the likelihood of tree breakage increases and these broken trees can fall on buildings (Twisdale 2005). Duryea et al. (1996) found that isolated trees were damaged more in hurricanes than those grouped together. However, few property owners recognize that trees can be managed to reduce risk; removal is not the only option (Peacock et al. 2005).

Stem taper and crown characteristics impact stability of trees (Valinger et al. 1993). Trees with less taper and those with most of the crown located high off the ground are more likely to fail in windstorms (Brudi and van Wassenaer 2002). Trees that are less tapered are more likely to fail in snow and wind events (Petty and Worrell 1981; Galinsky 1989). Trees grown with good trunk taper resulting from wide spacing and stand thinning are less susceptible to breakage than trees with poor taper (Petty and Worrell 1981).

Slender trees in dense stands can stand in storms because they are sheltered from direct winds by surrounding trees (Persson 1972). Tree stands are sometimes thinned to allow remaining trees to grow larger. Trees in thinned stands can develop good taper, larger crowns, and good root systems; and these characteristics can result in better stability compared with trees in denser stands (Petty and Worrell 1981; Valinger et al. 1993). However, if wind occurs soon after the thinning operation, wind can penetrate the stand and damage trees before they have time to respond to the thinning. Damage to a thinned stand of trees decreases with time (Shepard 1975; Lohmander and Helles 1987). Wind flowing through and around tree crowns has been extensively studied in dense forest stands (Massman 1987); however, no studies were found of wind flow through single trees grown in more open areas typical of planted trees in urban or suburban landscapes.

Lions tailing is a form of crown raising that removes most small-diameter interior branches along main scaffold branches and is not recommended (American National Standards Institute 2001) because it can potentially reduce stem and branch taper. This pruning treatment on very small Acer rubrum and Quercus virginiana trees ( 5 to $8 \mathrm{~cm}$ [2 to 3.2 in] diameter) has not resulted in greater overturning moment or tree movement in controlled wind tests compared with nonpruned trees or trees pruned in other manners (Smiley and Kane 2006; Gilman et al. 2008) probably because in both studies, trees were subjected to wind fields immediately after pruning. Branches could develop poor taper in the years after lions tailing making them more susceptible at that time; no studies have been conducted to test this hypothesis.

Rottmann's (1985) data help create a case against lions tailing and overraising the crown, which force trees to grow taller and, in some cases, wider. This places more mass farther from the ground, which increases forces at the base of the tree and likelihood of failure (Peltola et al. 1999). Trees with a lower center of gravity are less likely to break than those with a higher center of gravity (Rottmann 1985). Reducing the length of certain branches helps create a lower center of gravity on those branches and might help contribute to their survival in windstorms. Reducing the entire crown size would also theoretically reduce damage potential, at least temporarily.

Pine and spruce, both with one dominant trunk and an excurrent habit, appear less likely to fail from wind than from snow loads. Ice and snow loading reduces the wind speed needed to tip trees over in storms (Peltola et al. 1997). Luley and Bond (2006) found that susceptibility to damage and subsequent recovery after ice storms vary considerably with tree species. Certain species tend to have a more dominant trunk than others; although not measured, this may have contributed to some of the differences in storm susceptibility. Branches that are small compared with the trunk diameter are less likely to fail at the union than branches that are large compared with the trunk (Gilman 2003).

Force of the wind increased exponentially with increasing wind speed according to Moore and Maguire (2002), but Raymer (1962) and others (Cullen 2005) showed that force on a tree crown increased about linearly with increased wind speed attributable to the reconfiguration of the crown, especially at higher wind speeds. Wind-induced forces on trees may increase more or 
less linearly with wind speed until the crown cannot reconfigure itself in the wind and then more exponentially at higher wind speeds. This debate will continue for a long time because it is difficult to measure forces and reconfiguration on large trees (Cullen 2005). Wind speed also increases with distance from the ground making taller trees more likely to receive damage than shorter trees (Niklas and Spatz 2000). These complex and poorly understood relationships make utilization of theoretical models predicting trunk movement and subsequent damage difficult to use in practice.

The objective of this study was to determine how tree trunk movement was impacted by winds up to hurricane force after applying different pruning types to the crown. We measured movement with the assumption that more movement would equate to more damage to the tree, an assertion supported by others (James et al. 2006).

\section{MATERIALS AND METHODS}

In August 2001, we planted 80 cutting-propagated (clones) \#1 liners of Quercus virginiana Cathedral Oak ${ }^{\circledR}$ live oak in a field with sandy soil (Millhopper sand). Trees were located at the University of Florida Great Southern Tree Conference demonstration site in Alachua County, Florida, U.S. (U.S. Department of Agriculture 1990 hardiness zone 8), spaced on $2.4 \mathrm{~m}(7.92 \mathrm{ft})$ centers in eight rows $3.6 \mathrm{~m}(11.88 \mathrm{ft})$ apart. All trees were drip-irrigated three times daily in the growing season and less often in the cooler months. All trees were pruned twice each year to one central leader through 2004.

Trees were fertilized using 16:4:8 $\left(\mathrm{N}_{2} \mathrm{P}_{2} \mathrm{O}_{5}: \mathrm{K}_{2} \mathrm{O}\right.$; Parker's Super Soilife; Chemsico Inc., Division of United Industries Co., St. Louis, MO). In January 2002, the amount applied was $65 \mathrm{~g}$ (2.28 oz); in May 2002, $210 \mathrm{~g}$ (7.35 oz); and July 2002, $300 \mathrm{~g}$ (10.5 $\mathrm{oz})$. Thereafter, trees received $400 \mathrm{~g}$ (14 oz) three times per year, in February or March, May, or June. Every other tree was removed from the field November 2004; in June 2006, every other tree was again removed leaving 20 trees for this study spaced 9.7 $\mathrm{m}(32 \mathrm{ft})$ apart within rows and $7.3 \mathrm{~m}(24 \mathrm{ft})$ apart between rows.

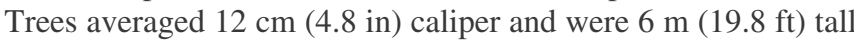
with a $2.7 \mathrm{~m}(8.9 \mathrm{ft})$ wide canopy.

Pruning types were defined in the American National Standard for Tree Care Operations (American National Standards Institute 2001). Pruning treatments tested were crown raised, reduced, thinned, and nonpruned control trees. Trees were randomly assigned to a pruning type. Pruning types were blocked in time so that each block contained one raised, thinned, reduced and a nonpruned tree. One person executed all pruning to maintain treatment consistency. Trees were pruned in the week before subjecting them to wind.

Raising the crown removed branches back to the single central trunk beginning at the bottom of the crown and working upward; mean number of cuts was 11.2 with a diameter of $27.9 \mathrm{~mm}$ (1.1 in). Thinning removed branches back to the trunk throughout the entire crown in a visual attempt to evenly distribute remaining foliage throughout the crown; mean number of cuts was 12.2 with a diameter of $28.1 \mathrm{~mm}$ (1.1 in). Reduction made one cut through the trunk at the point that removed the targeted pruning dose from the top of the tree; mean cut diameter was $71 \mathrm{~mm}(2.8$ in). Thirty-three percent of the foliage was the targeted pruning dose for all 15 pruned trees.

The relationship between branch diameter at the trunk and foliage weight on those branches was used to estimate the amount of foliage removed. This relationship was calculated by removing 15 branches from three extra trees removed before testing with a trunk caliper closest to the mean trunk diameter for test trees (12 cm [4.8 in]) for a total of 45 data points; five branches on each tree were in the top third of the crown, five were in the middle third, and five were in the bottom third of the crown. Branch diameter was measured where each branch met the trunk and all foliage was stripped from the branch and weighed fresh. A curve relating branch diameter to foliar fresh weight was calculated (Figure 1). Pulling all foliage from these three test trees gave the total foliar weight in the crowns from which an average was calculated. Once the average total foliar weight of these three trees was determined, the branch diameter squared corresponding to $33 \%$ of this number (Figure 1) was removed from each of the 15 pruned trees. Branches were pruned one by one and their squared diameters were summed. Pruning stopped on a tree once the sum of the squared diameters reached the point on the curve that was equal to $33 \%$ of average total canopy foliage weight.

The soil was brought to field capacity within a $10 \mathrm{ft}(3 \mathrm{~m})$ diameter circle centered on the trunk so that soil conditions would be similar for each tree tested. This was done by calculating the amount of water required to bring soil within the top $0.6 \mathrm{~m}(1.98 \mathrm{ft})$ to field capacity $\left(1.4 \mathrm{~m}^{3}\left[49 \mathrm{ft}^{3}\right]\right)$ and then applying 1.5 times that amount of water before testing each tree. Water was applied $6 \mathrm{hr}$ before blowing trees. This allowed water to percolate into the soil and drain bringing it to field capacity.

An airboat fan assembly created a large enough wind field to immerse the test trees. Power generation consisted of two stacked 496 in $^{3}(8,267 \mathrm{~mL})$ Chevrolet marine engines with Airboat Drive Units $\mathrm{CH} 3$ belt-driven reduction assembly. The drive units spun two $2 \mathrm{~m}(6.6 \mathrm{ft})$ long counterrotating propellers, which produced approximately $45 \mathrm{~m} / \mathrm{s}(110 \mathrm{mph})$ wind speeds at maximum throttle. Two portable walls each $3.7 \times 3.7 \mathrm{~m}(12.21$ $\times 12.21 \mathrm{ft}$ ) were positioned between the propellers and the tree $2.4 \mathrm{~m}(7.92 \mathrm{ft})$ apart parallel to the wind field to confine the wind flow field and to improve flow uniformity. The walls began at the propellers and ended $1.5 \mathrm{~m}(4.95 \mathrm{ft})$ from the trunk. Behind the tree being tested was a $45^{\circ}$ wind deflector, which protected the next tree in line to be tested.

Control and data acquisition were integrated into one system built from PXI hardware, 16-bit Series Multifunction DAQ devices, and Labview software National Instruments (Austin, TX). At $20 \mathrm{~ms}$ intervals, serial port commands were sent to a

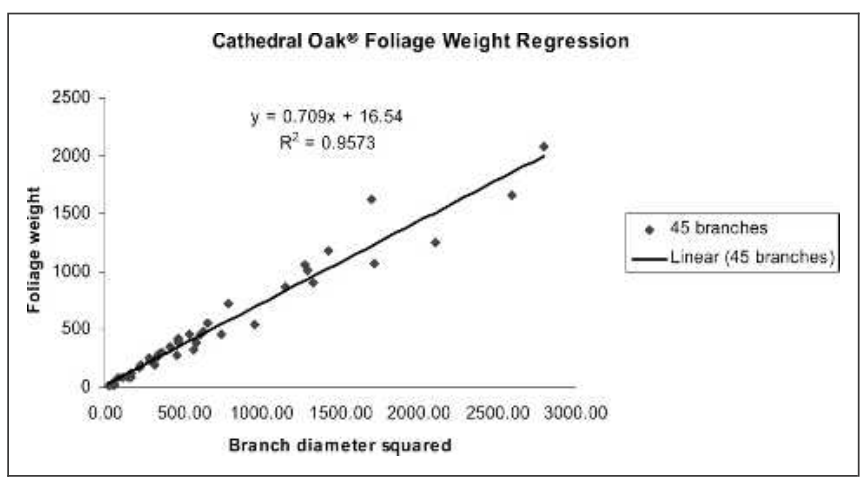

Figure 1. Relationship between fresh foliage weight and diameter of the branch on which foliage was borne on $\mathbf{4 5}$ branches from three trees. 
Pololu USB 16-Servo Controller that used pulse width modulation to control Hitec HS-5985MG digital coreless ultratorque servos attached to the engine throttle bodies (Hitec RCD USA, Poway, CA). Revolutions per minute (rpm) feedback was measured directly from the engine's tachometer signal. To achieve maximum resolution, each tachometer measurement operated separately of the other engine and the data acquisition system for the test instruments. At 4,500 rpm, engine resolution was on the order of 10 to $20 \mathrm{rpm}$.

A RM Young wind monitor (Campbell Scientific, Logan, UT) measured wind speed at $2 \mathrm{~m}(6.6 \mathrm{ft})$ above the ground at the exit of the portable wall assembly $1.5 \mathrm{~m}(4.95 \mathrm{ft})$ in front of the crown. Dynamic characteristics of the anemometer's four-blade polypropylene helicoid propellers include a $2.7 \mathrm{~m}(8.91 \mathrm{ft}) 63 \%$ recovery distance constant and a damped natural wavelength of $7.4 \mathrm{~m}(24.42 \mathrm{ft})$. The wind monitor $50 \%$ recovery vane delay distance was $1.3 \mathrm{~m}(4.29 \mathrm{ft})$ and is rated for a $100 \mathrm{~m} / \mathrm{s}(244 \mathrm{mph})$ gust survival.

The trees were instrumented on the leeward side of the trunk at three levels from the ground (104 to $109 \mathrm{~cm}$ [41.6 to $43.6 \mathrm{in}$ ], 180 to $196 \mathrm{~cm}$ [72 to $78.4 \mathrm{in}$ ], and 258 to $274 \mathrm{~cm}$ [103.2 to 109.6 in]) with Microstrain 3DM-GX1 orientation sensors (Williston, VT) that measured pitch away from the wind in degrees from vertical at $50 \mathrm{~Hz}$ (50 times each second). An embedded processor compensated for temperature and linear acceleration and performed a 16-bit A/D conversion; orientation resolution was less than $0.1^{\circ}$. An optional analog mode was enabled that reconstructed the output at 12-bit resolution. All three sensors were individually powered, and data were recorded as differential inputs. The center orientation sensor was positioned at the estimated crown center of gravity; the other two sensors were approximately $75 \mathrm{~cm}$ (30 in) above and below this point. The center of gravity was estimated by measuring all branch diam- eters (just beyond the branch union with the trunk) on three test trees, summing their branch cross-sectional areas, and moving up the crown until half the cross-sectional area was above and half below. The average center of gravity from these three trees was used as the center of gravity for all 20 trees in the study.

The testing protocol included a 2-min linear increase in wind speed from $10 \mathrm{~m} / \mathrm{s}(24 \mathrm{mph})$ to $45 \mathrm{~m} / \mathrm{s}(110 \mathrm{mph})$, at which time the engines maintained a constant rpm for $3 \mathrm{~min}$. Three rudders were positioned just downstream of the propellers to break up the swirl from the downstream propeller. Wind speed traces for each of the 20 tests are shown in Figure 2. Variability between mean wind speed and gustiness is noted. These inconsistencies are a result of engine drift (equipment was relocated for each test) and environmental wind conditions. Maximum wind speeds reported by the ASOS station at the nearest airport (KGNV) during 31 May and 5 June 2006 reached $7 \mathrm{~m} / \mathrm{s}(17 \mathrm{mph})$ in the late afternoon. Their contribution is also noted in the longitudinal turbulence intensity (the coefficient of variation of the component parallel to the mean wind direction), which varied from $1.1 \%$ to $3.1 \%$.

The 50 measurements each second of wind speed and trunk bending angle at each of the three trunk positions were averaged to calculate a mean for each second; data were graphed as bending angle versus wind speed for each inclinometer. Linear and quadratic functions predicting trunk bending angle from wind speed were calculated using SAS GLM (SAS Institute, Cary, NC). Analysis of variance (ANOVA) as a randomized complete block design was used to compare bending angle among pruning treatments at various wind speeds. Maximum bending angle minus minimum bending angle during the first minute of maximum wind (approximately $45 \mathrm{~m} / \mathrm{s}$ [110 mph]) was calculated for each tree. Number of broken branches on each tree was counted and comparisons among treatments made with ANOVA. Duncan's

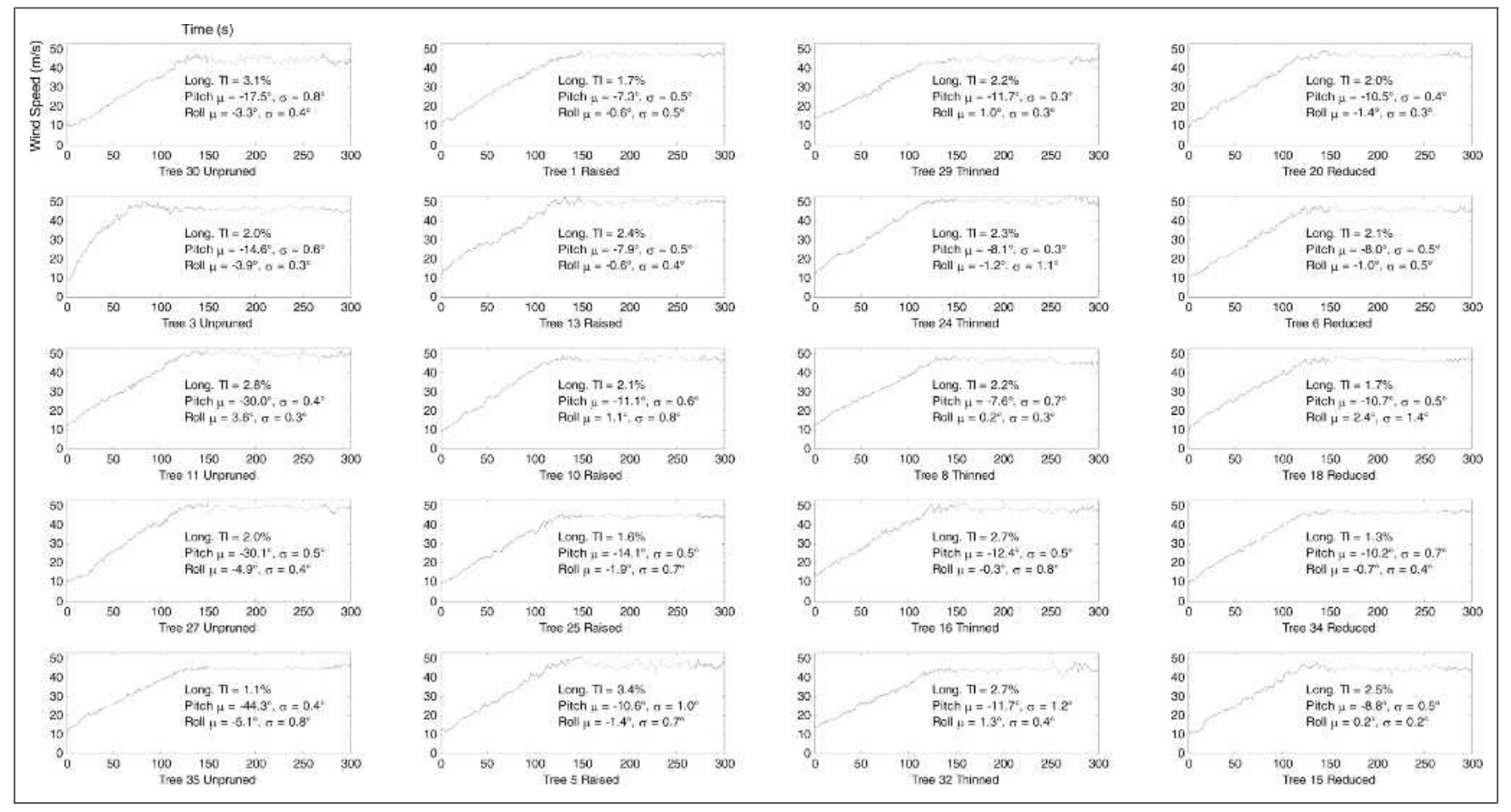

Figure 2. Wind speed traces of each tree tested showing wind speed over the 300 sec long test. 
multiple range test (MRT) was used to make comparisons among means when appropriate.

\section{RESULTS AND DISCUSSION}

Trees in all treatments never stopped reconfiguring crown shape as shown by the increased trunk bending with speed up to $45 \mathrm{~m} / \mathrm{s}$ (110 mph) (Figures 3-5). Crown reconfiguration dissipates wind-induced forces in trees (Vogel 1996). There was no difference among treatments in the quantity maximum bending angle minus minimum bending angle (amplitude) during the first minute of maximum wind (approximately $45 \mathrm{~m} / \mathrm{s}$ [110 mph]) indicating similar trunk amplitude for pruned and nonpruned trees (data not shown). The trees were either too small or the wind speed too constant to cause trees to sway like mature trees (James et al. 2006).

All three pruning types reduced $(P<0.01)$ trunk motion as measured by bending angle at all wind speeds in the lower (Figure 3) and middle crown (Figure 4) compared with trees that were not pruned. Trunks subjected to less harmonic motion experience less load forces, which increases tree stability (James et al. 2006), indicating that pruning reduces potential damage in wind. The three pruning types had similar bending angles at all wind speeds except at the top-most orientation sensor (upper crown) where reduced trees bent less than raised trees (Table 1). Each of the five reduced trees moved identically (Figures 3-5), whereas there was more variability from tree to tree in all other treatments.

Reduced and thinned trees bent in the upper crown significantly less $(P<0.01)$ than nonpruned trees probably because there was less foliage up high compared with nonpruned trees. In contrast, the upper crown of raised trees responded similar to trees that were not pruned (Figure 5; Table 1). This concurs with Brudi and van Wassenaer (2002) who found that in wind, foliage positioned at the top of trees resulted in greater force on the trunk than the same amount of foliage borne on branches closer to the ground. Moore and Maguire $(2002,2005)$ and others also showed that removing branches (pruning) changed the sway motion of the trunk, but they indicated that more than $80 \%$ of the crown mass had to be removed from the lower trunk to significantly reduce sway. We found significant reduction in motion with just $33 \%$ of foliage removed. The strict excurrent growth habit on these conifers was quite different from the habit on our trees so direct comparison to our data could be misleading.

At $45 \mathrm{~m} / \mathrm{s}$ (110 mph), the average maximum angle of deflection for the topmost orientation sensor on the five nonpruned trees was $45.8^{\circ}$ (Figure 5). This was not surprising because the biggest crowns, and thus the largest exposed projected frontal area, would catch the most wind causing greater drag (Rudnicki et al. 2004). Of the 20 trees tested, the one that had the most trunk deflection was a nonpruned tree that bent over at the top

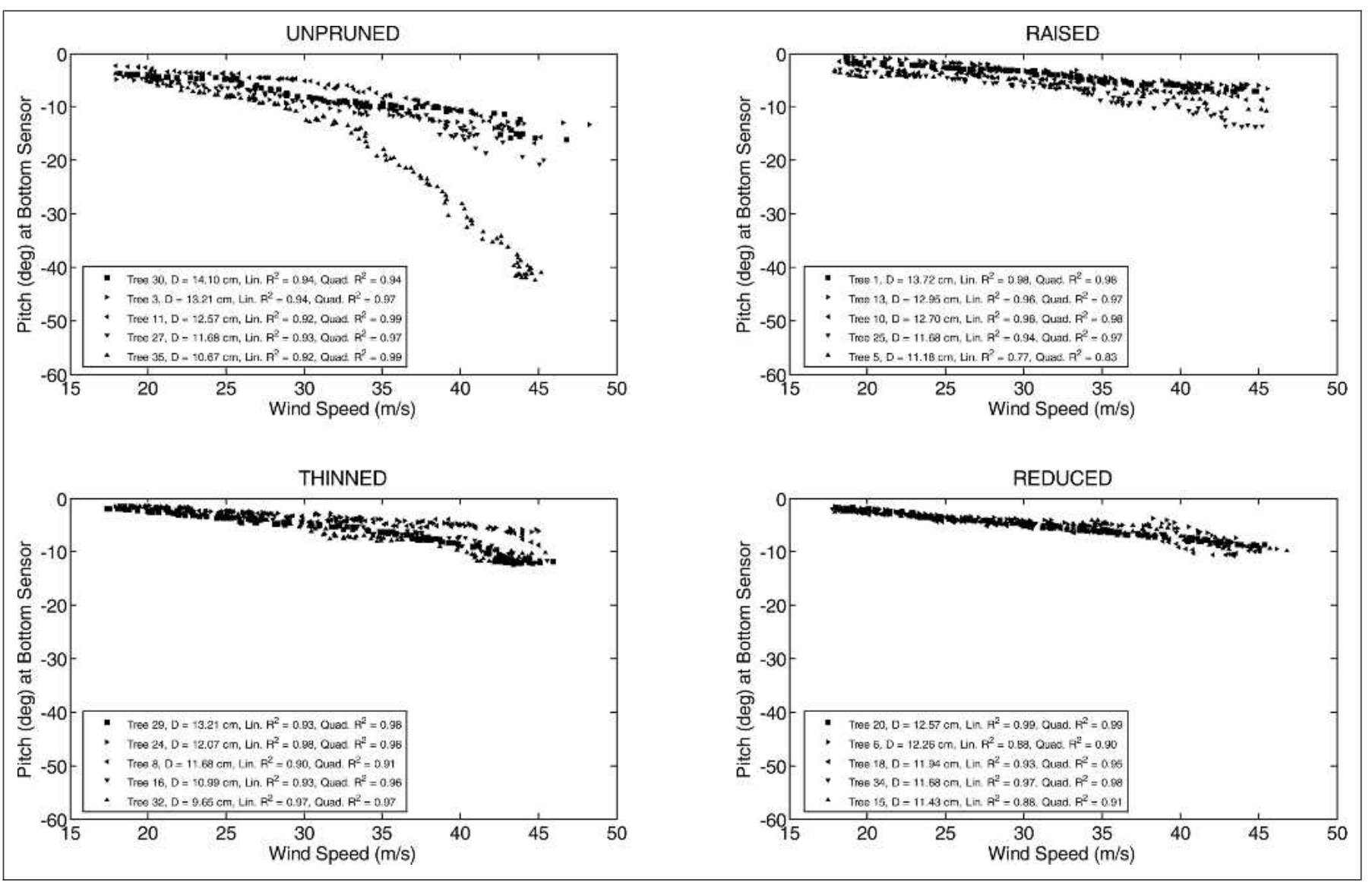

Figure 3. Pitch (bending angle from vertical) of the trunk $75 \mathrm{~cm}$ (30 in) below the estimated center of gravity in the canopy blown from $15 \mathrm{~m} / \mathrm{s}(37 \mathrm{mph})$ to $45 \mathrm{~m} / \mathrm{s}(110 \mathrm{mph})$ for 20 trees receiving four pruning types. Each data point is the mean of 50 data points collected each second. 


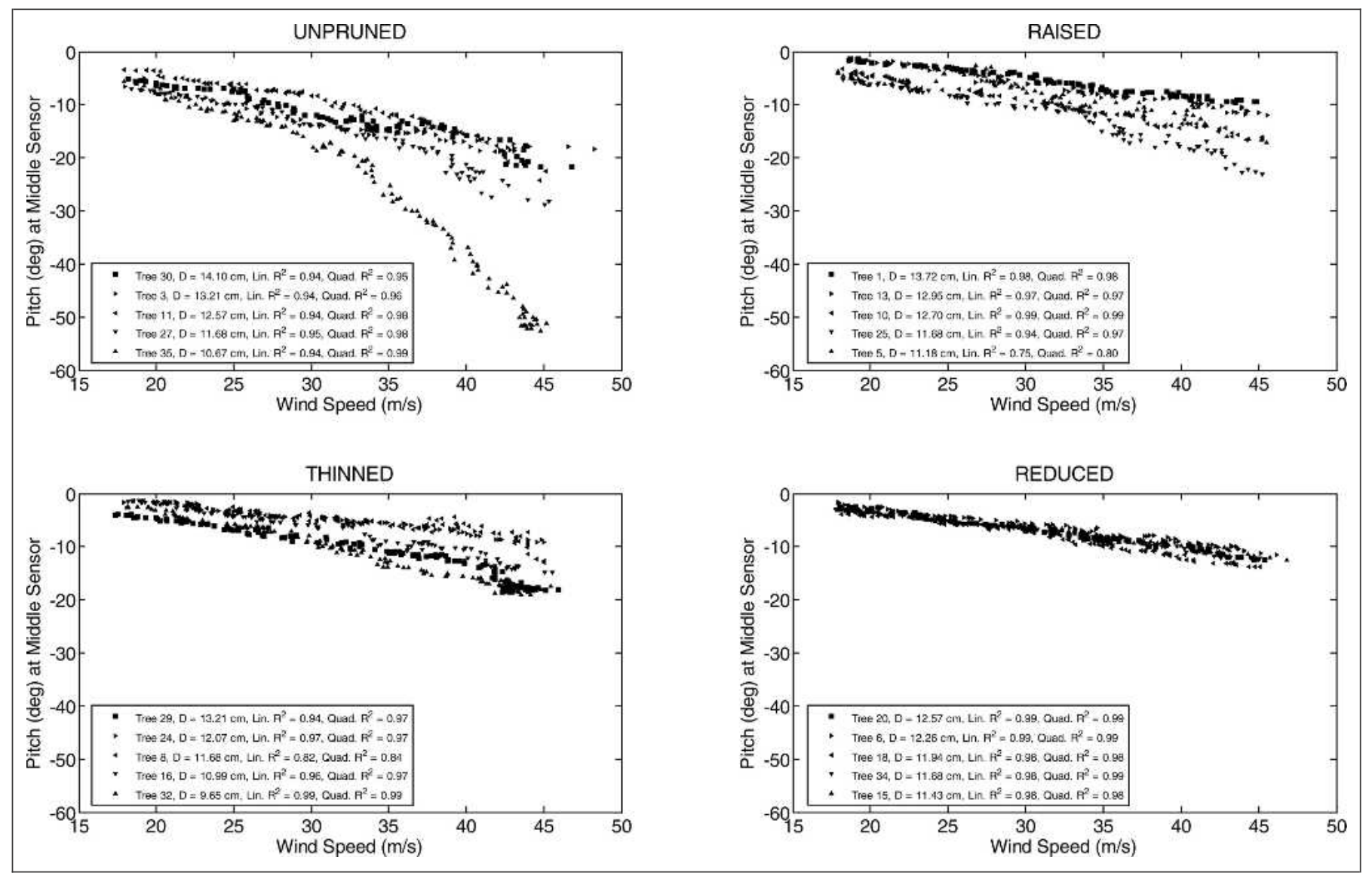

Figure 4. Pitch (bending angle from vertical) of the trunk in the estimated center of gravity in the canopy blown from $15 \mathrm{~m} / \mathrm{s}$ ( 37 $\mathrm{mph}$ ) to $45 \mathrm{~m} / \mathrm{s}$ (110 mph) for 20 trees receiving four pruning types. Each data point is the mean of 50 data points collected each second.

orientation sensor $64.2^{\circ}$ from its original position (Figure 6 ). The lower portion of the trunk on this tree cracked in compression on the leeward side approximately $60 \mathrm{~cm}$ (24 in) from the ground. No other trunks cracked.

The similar bending angle among pruning types at the lowest and middle orientation centers might be explained by crown reconfiguration, which is the speed-specific reorientation of branches and leaves in the wind. Foliage on raised trees was borne on smaller-diameter branches (data not shown), which bent more into the windstream than larger branches. Branches on thinned trees may have been able to reconfigure into the holes created by pruning to allow air to pass through the crown as shown by Grant and Nickling (1998). Foliage on reduced trees was born on larger-diameter, stiffer branches lower in the crown, which likely bent less (videos of each tree suggested this). Stiffer branches likely resulted in less reconfiguration and a greater frontal area exposed to wind on reduced trees than raised and thinned trees. Despite the possible larger frontal area for reduced trees, force on the lowest and middle inclinometer positions may have been the same as on the other two pruning treatments because of reduced length of the lever arm in reduced trees.

The raising and reducing techniques were similar in that they reduced the size (at-rest projected frontal area) of the crown but in different places. However, the data showed trees pruned in these two ways reacted to wind loading very differently. Concentration of mass at the top of raised trees contributed to them bending over at the top of the crown almost twice as much as reduced trees (Table 1) as Brudi and van Wassenaer (2002) found. This dramatic $(P<0.01)$ increase in deflection on raised trees in the upper crown was dissipated by bending along the upper trunk and was not transferred to the lower portion of the trunk as shown by similar incline to reduced trees on the lowest inclinometer. Although this occurred on our young trees, wood in older trees is stiffer so it bends less (Bertram 1989). As a result, older trees may not respond as our young trees did. Instead of the force dissipating into trunk bending, the stiffer wood on older trees would transfer more of this force to the base of large branches and to the trunk increasing the likelihood of trunk and large branch failure on raised trees (Rottmann 1985; Brudi and van Wassenaer 2002). Raised trees in our study would be similar to overlifted or lions tailed trees in the landscape.

It should be noted that we could have underestimated trunk deflection for the raised trees. Our wind field extended $5.5 \mathrm{~m}$ $(18.15 \mathrm{ft})$ aboveground level, and two raised trees stood at $6.7 \mathrm{~m}$ $(22.11 \mathrm{ft})$ so their crowns were not entirely within the wind field (although crown deflection under wind loading lowered the

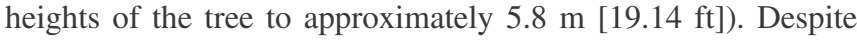
this limitation, those trees partially out of the main wind field responded similarly to those inside the wind field (Figures 3-5). The nonpruned and thinned trees' crowns were also not completely within the wind field before testing; however, once wind began to blow the trees, it caused them to reconfigure their branches and bend into the field. Reduced trees were within the wind field before testing began. Mayhead (1973) noted that the 


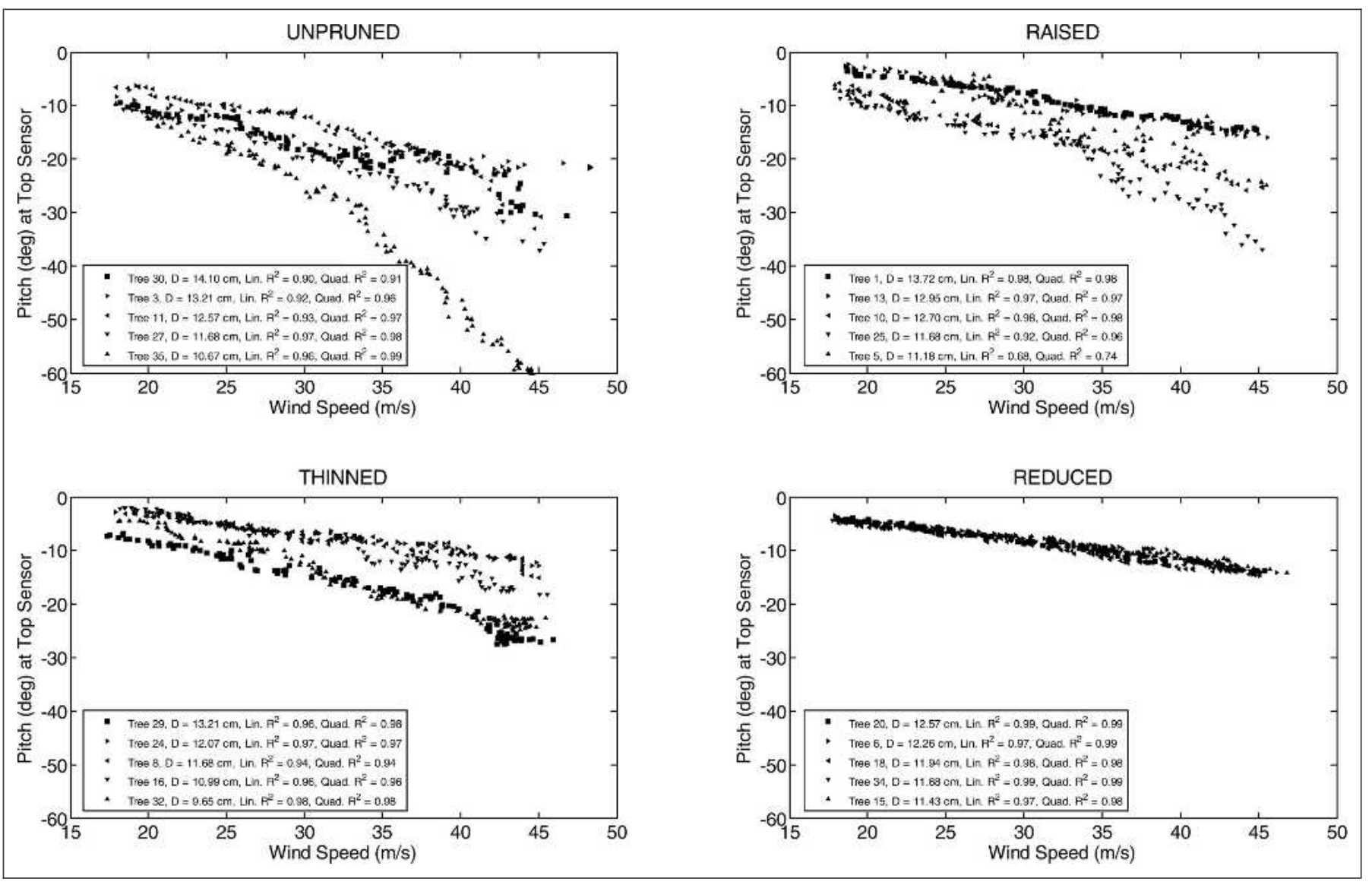

Figure 5. Pitch (bending angle vertical) of the trunk $75 \mathrm{~cm}(30 \mathrm{in})$ above the estimated center of gravity in the canopy blown from $15 \mathrm{~m} / \mathrm{s}(37 \mathrm{mph})$ to $45 \mathrm{~m} / \mathrm{s}(110 \mathrm{mph})$ for 20 trees receiving four pruning types. Each point is the mean of 50 data points collected each second.

leading shoots of several trees he tested were outside the wind flow and commented that it was likely an insignificant source of error.

Thinned trees bent over in the upper crown almost half as much as nonpruned trees. There are at least two explanations for this. First, thinning did not reduce the size (dimensions) of the crown as did the other two pruning types; however, porosity increased. Although we did not measure crown porosity, voids were obvious after pruning. Removing branches back to the trunk throughout the crown allowed wind to pass through the crown, which reduced force on the main trunk and subsequent movement (Grant and Nickling 1998). Instead of passing

Table 1. Slope (bending angle from vertical) away from the wind source of the top, middle, and bottom orientation sensors on trees pruned with four different types and blown in $45 \mathrm{~m} / \mathrm{s}$ (110 mph) winds. ${ }^{\mathrm{z}}$

\begin{tabular}{llll}
\hline & $\begin{array}{l}\text { Bottom sensor } \\
75 \mathrm{~cm}(30 \mathrm{in}) \\
\text { below center } \\
\text { of gravity }\end{array}$ & $\begin{array}{l}\text { Middle sensor } \\
\text { at center } \\
\text { of gravity }\end{array}$ & $\begin{array}{l}\text { Top sensor } \\
75 \mathrm{~cm}(30 \mathrm{in}) \\
\text { above center } \\
\text { of gravity }\end{array}$ \\
\hline Pruning type & $27.0 \mathrm{a}$ & $35.7 \mathrm{a}$ & $45.8 \mathrm{a}$ \\
Not pruned & $9.8 \mathrm{~b}$ & $19.1 \mathrm{~b}$ & $30.8 \mathrm{ab}$ \\
Raised & $12.1 \mathrm{~b}$ & $15.2 \mathrm{~b}$ & $23.1 \mathrm{bc}$ \\
Thinned & $10.3 \mathrm{~b}$ & $12.6 \mathrm{~b}$ & $16.9 \mathrm{c}$ \\
Reduced &
\end{tabular}

${ }^{\mathrm{z}}$ Means (of five trees) in a column followed by a different letter are statistically different at $P<0.01$. through the crown, wind had to push against and deflect around the crown in the other three treatments. This occurs in the forest when stands are thinned (by removing entire trees) and can cause more trees to fall than in a nonthinned stand (Gardiner et al. 2005). Second, branches on thinned trees appeared to move more than branches on other treatments, but branches did not appear to be moving in the same direction at the same time. This chaotic movement may have acted as a buffer to dampen (reduce) motion (Moore and Maguire 2005; James et al. 2006) resulting in less trunk movement (Figure 5). Increased motion of branches in the landscape could result in more broken branches instead of a broken trunk as occurred on one nonpruned tree. Thinning could provide the tree a means of shedding wind load; branches might break as a result of increased motion, thus preserving the trunk.

Response of thinned trees appears to conflict with Gilman et al. (2008) who found that at wind speeds over $20.1 \mathrm{~m} / \mathrm{s}$ (45 mph) crown thinning was less effective at reducing trunk movement than reducing. However, thinning in Gilman et al. (2008) removed twigs only from the outer portion of the crown creating very small voids in the crown edge, whereas thinning in the current study removed branches entirely back to the trunk. The large voids we created in the crown may have accounted for less trunk movement.

Foliage lost as a result of wind occurred with all trees in all treatments. However, the trunks did not drift back toward the wind source during the $3-\min 45 \mathrm{~m} / \mathrm{s}(110 \mathrm{mph})$ wind event 


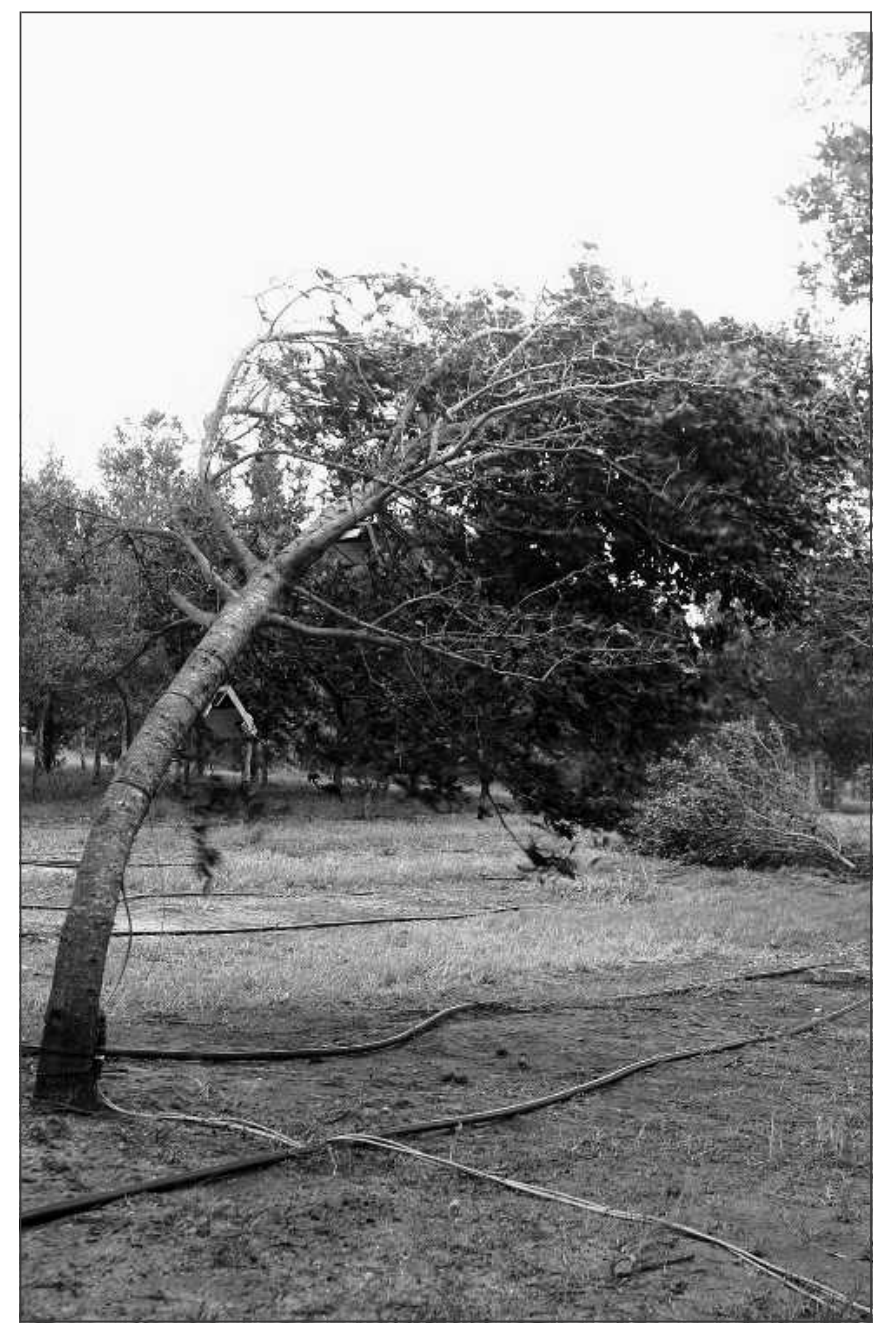

Figure 6. Tree that was not pruned bending with $45 \mathrm{~m} / \mathrm{s}$ (110 mph) wind. The lower (just below canopy) and middle (inside canopy) orientation sensors are shown mounted on a bracket constructed of metal and wood. The top sensor is hidden higher in the crown. Three wires are shown on the trunk and ground; each sends sensor data to the Multifunction DAQ.

because foliage was lost (data not shown). This indicates that the mass and projected frontal area of trunk, branches, and twigs played a large role in trunk movement of live oak in wind, although force on the trunk in the dormant season for deciduous trees was reported much lower than in summer (Baker 1997). Raised trees appeared to have lost the least amount of foliage, although this was not measured. This may have occurred because most of the branches in the crown were bent over in a streamlined fashion similar to a nursery tree or conifer tied up for shipping. This form probably allowed wind to pass under and up the reconfigured crown. At high wind speeds, air was essentially pushing up the bent trunk oppressing branches against the single trunk (Figure 6). With most or all branches and twigs aligned with the wind on raised trees, leaves could have been oppressed to the twigs in a fashion that compressed the axial bud. Foliage may be better connected to the twig when subjected to forces in this direction than in other directions (Niklas 1996). In addition, small twigs and branches on raised trees were packed into a tight, flexible reconfigured crown that appeared to move more or less as a single mass in the wind. This could have protected many leaves from direct wind exposure such as occurs in a nonthinned forest (Gardiner et al. 2005).

In reduced and thinned trees, wind was blowing against areas of the crown where the trunk was more upright than on raised trees, which were bending over more near the top of the tree (Figure 5). This resulted in branches on reduced and thinned trees projecting straighter into the wind field instead of being pushed up against the single trunk as occurred on raised trees. This could have allowed more wind to flow into the reduced and thinned crowns causing more defoliation. Few others have studied this, although Zhu et al. (2000) reported that wind speed inside the crown of a nonpruned Japanese pine (Pinus thunbergii) was approximately half that experienced on the outside of the crown. This probably explains why foliage was not lost from the leeward side of the crown.

Branches broke on the windward side of the lower crown on several trees. Longitudinal compression cracks were evident on all broken branches; tension cracks appeared on only a few broken branches. Cracks appeared at the point where branches twisted or bent dramatically while reconfiguring in the wind. There were no differences in the number of broken branches among pruning treatments (data not shown); however, thinned trees had more bark damage on branches than other treatments. Watching the video of each tree showed that branches on thinned trees moved more than branches on all other treatments.

In conclusion, removing branches from the crown of live oak reduced trunk movement in wind. Although this result was expected, we quantified the relationship showing that removal of $33 \%$ of the foliage with reduction or thinning pruning types resulted in less than half the movement compared with nonpruned trees. Reduced motion likely resulted in lesser forces transferred to the trunk (Kerzenmacher and Gardiner 1998) and reduced likelihood of trunk failure in wind. This effect is likely a combination of reduced frontal area, reconfigured crown shape, and mass damping (James et al. 2006). Thinning and reduction appeared most effective at reducing trunk movement in the upper crown. Lions tailing or crown raising appeared ineffective at reducing upper trunk movement in windstorms. All pruning types reduced lower trunk movement by the same amount compared with nonpruned trees. Much more research is needed, including the testing of different species, different pruning doses, larger trees, gusty winds, and testing the effect of wind for longer durations. In addition, we know nothing about how long the pruning effect on movement described will last.

\section{LITERATURE CITED}

American National Standards Institute. 2001. American National Standard for Tree Care Operations-Tree, Shrub, and Other Woody Plant Maintenance-Standard Practices (Pruning) (A300, Part 1). National Arborist Association, Inc., Manchester, NH.

Baker, C.J. 1997. Measurements of the natural frequencies of trees. Journal of Experimental Botany 48:1125-1132.

Bertram, J.E.A. 1989. Size-dependent differential scaling in branches: The mechanical design of trees revisited. Trees Structure and Function 4:241-253.

Brudi, E., and P. van Wassenaer. 2002. Trees and statics: Nondestructive failure analysis. In Tree Structure and Mechanics Conference Proceedings. Smiley, T.E., and Coder K. (Eds.). Intern. Soc. Arboriculture, Champaign IL. 
Cook, R.A. 1990. Hurricane Hugo vs. critical lifelines-Lessons learned and implications for the future. Proceedings of Hurricane Hugo One Year Later. 13-15 September.

Cullen, S. 2005. Trees and wind: A practical consideration of the drag equation velocity exponent for urban tree risk management. Journal of Arboriculture 31:101-113.

Duryea, M.L., G.M. Blakeslee, W.G. Hubbard, and R.A. Vasquez. 1996. Wind and trees: A survey of homeowners after Hurricane Andrew. Journal of Arboriculture 22:44-50.

Galinsky, W. 1989. A windthrow-risk determination for coniferous trees. Forestry 62:139-146.

Gardiner, B., B. Marshall, A. Achim, R. Belcher, and C. Wood. 2005. The stability of different sylvicultural systems: A wind-tunnel investigation. Forestry 78:471-483.

Gilman, E.F. 2003. Branch to stem diameter ratio affects strength of attachment. Journal of Arboriculture 29:291-294.

Gilman, E.F., J. Grabosky, S. Jones, and C. Harchick. 2008. Effects of pruning dose and type on tree response in tropical storm winds. Journal of Arboriculture and Urban Forestry 34:13-19.

Grant, P.F., and W.G. Nickling. 1998. Direct measurement of wind drag on vegetation for application to windbreak design and modeling. Land Degradation and Development 9:57-66.

James, K.R., N. Haritos, and P.K. Ades. 2006. Mechanical stability of trees under dynamic loads. American Journal of Botany 93: $1522-1530$.

Kerzenmacher, T., and B. Gardiner. 1998. A mathematical model to describe the dynamic response of a spruce tree to the wind. Trees (Berlin) 12:385-394.

Lohmander, R.S., and F. Helles. 1987. Windthrow probability as a function of stand characteristics and shelter. Scandanavian Journal of Forest Research 2:227-238.

Luley, C.J., and J. Bond. 2006. Evaluation of the fate of ice stormdamaged urban maple (Acer) tree. Arboriculture and Urban Forestry 32:214-220.

Massman, W. 1987. A comparative study of some mathematical models of the mean wind structure and aerodynamic drag of plant canopies. Boundary-Layer Meteorology 40:179-197.

Mayhead, G.J. 1973. Some drag coefficients for British forest trees derived from wind tunnel studies. Agricultural and Forest Meteorology 12:123-130.

Moore, J.R., and D.A. Maguire. 2002. The mechanics of trees under wind loading. In Tree Structure and Mechanics Conference Proceedings. Smiley, T.E., and Coder, K. (Eds.). International Society of Arboriculture, Champaign, IL.

. 2005. Natural sway frequencies and damping ratios of trees: Influence of crown structure. Trees (Berlin) 19:363-373.

Niklas, K. 1996. Differences between Acer saccharum leaves from open and wind-protected sites. Annals of Botany 78:61-66.

Niklas, K., and H.C. Spatz. 2000. Wind-induced stresses in cherry trees: Evidence against the hypothesis of constant stress levels. Trees, Structure and Function 14:230-237.

Peacock, W.G., S.D. Brody, and W. Highfield. 2005. Hurricane risk perceptions among Florida's single family homeowners. Landscape and Urban Planning 73:120-135.

Peltola, H., M. Nykanen, and S. Kellomaki. 1997. Model computations on critical combinations of snow loading and windspeed for snow damage of scots pine, Norway spruce and birch sp. at stand edge. Forest Ecology and Management 95:229-241.

Peltola, H.M., S. Kellomaki, H. Vaisanen, and V.P. Ikonen. 1999. A mechanistic model for assessing the risk of wind and snow damage to single trees and stands of Scots pine, Norway spruce, and birch. Canadian Journal of Forest Research 29:647-661.

Persson, P. 1972. Stand treatment and damage by wind and snowSurvey of younger thinning experiments. Swedish University of Agriculture Science, Department of Forest Management [English abstract]. Rapporter och Uppsater 23:1-205.
Petty, J.A., and R. Worrell. 1981. Stability of coniferous tree stems in relation to damage by snow. Forestry 54:115-128.

Raymer, W.G. 1962. Wind resistance of conifers. National Physical Laboratory Aeronautical Report 1008:1-20. Aerodynamics Division, London, U.K.

Rottmann, M. 1985. Schneebruchschaden in Nadelholzbestanden Beitrage zur Beurteilung der Schneebruchgefahrdung, zur Schadensvorbeugung und Behandlung schneegesschadigter Nadelholzbestande. J.D. Sauerlander's Verlag, Frankfurt am Main. 159 pp.

Rudnicki, M., S.J. Mitchell, and M.D. Novak. 2004. Wind tunnel measurements of crown streamlining and drag relationships for three conifer species. Canadian Journal of Forest Research 34:666-676.

Shepard, R.K. 1975. Ice storm damage to loblolly pine in northern Louisiana. Journal of Forestry 73:420-423.

Smiley, T.E., and B. Kane. 2006. Effects of pruning type on wind loading. Journal of Arboriculture 32:33-39.

Twisdale, L.A. 2005. HAZUS-MH Technical Manual, Tree Blowdown. FEMA, Jesup, MD.

Valinger, E., L. Lundqvist, and L. Bondesson. 1993. Assessing the risk of snow and wind damage from tree physical characteristics. Forestry 66:249-260.

Vogel, S. 1996. Blowing in the wind: Storm-resisting features of the design of trees. Journal of Arboriculture 22:92-98.

Zhu, J., T. Matsuzaki, and K. Sakioka. 2000. Wind speeds within a single crown of Japanese black pine (Pinus thunbergii Parl.). Forest Ecology and Management 135:19-31.

Edward F. Gilman (corresponding author)

Professor

Environmental Horticulture Department

1543 Fifield Hall

University of Florida

Gainesville, FL 32611, U.S.

egilman@ulf.edu

Forrest Masters

Assistant Professor

Civil and Coastal Engineering Department

365 Weil Hall

PO Box 116580

University of Florida

Gainesville, FL 32611, U.S.

Jason C. Grabosky

Associate Professor

Rutgers University

Department of Ecology, Evolution and Natural Resources

14 College Farm Road, Room 144

New Brunswick, NJ 08901, U.S.

grabosky@aesop.rutgers.edu

Résumé. Le but était de déterminer comment différentes techniques d'élagage affectent le mouvement du tronc chez des chênes verts soumis à des vents d'ouragans. Le mouvement des arbres non élagués face au vent a été comparé à ceux dont la cime avait été éclaircie, réduite ou rehaussée. Vingt arbres ont été soufflés au moyen d'un générateur de vents jusqu'à $45 \mathrm{~m} / \mathrm{s}$ maintenu pendant 3 minutes. Des senseurs tridirectionnels avaient été fixés sur les arbres à différentes hauteurs prédéterminées le long du tronc pour mesurer sa déflection. L'éclaircissage ou la réduction de cime diminuait le mouvement de la section supérieure du tronc à toutes les vitesses de vents tandis que le rehaussement n'avait 
aucun effet. Le mouvement de la section inférieure du tronc n'était pas affecté par le type d'élagage. Ces données indiquent que les feuillage et les branches vers le sommet de la cime sont largement responsables dans le mouvement du tronc en ligne droite alors que celles vers le bas de la cime sont moins importantes à ce chapitre. Les arbres qui sont réduits ou éclaircis de la manière décrite pourraient être l'objet de moins de dommages lors de tempêtes de vents.

Zusammenfassung. Das Ziel war zu bestimmen, wie unterschiedliche Schnitttechniken die Stammbewegung von Eichen in stürmischen Winden beeinflussen. Bewegung von unbeschnittenen Bäumen im Wind wurde verglichen mit beschnittenen, reduzierten und ausgedünnten Bäumen. Zwanzig Bäume wurden mit einem Windgenerator (bis zu $45 \mathrm{~m} / \mathrm{s}$ ) über drei Minuten geblasen. Jeder Baum hatte drei Richtsensoren am Stamm, um die Deflektion zu messen. Ausdünnen oder Reduzieren der Krone verminderte deutlich die obere Stammbewegung bei allen Windstärken. Die Bewegung des unteren Stamms wurde nicht beeinflusst. Diese Daten zeigen, dass Blattwerk und Äste im oberen Teil des Baumes hauptsächlich für die Stammbewegung während Windböen verantwortlich sind. In dieser beschriebenen Weise reduzierte oder ausgedünnte Bäume erlitten weniger Schaden während heftiger Winde.

Resumen. El objetivo fue determinar cómo las diferentes técnicas de poda afectan el movimiento del tronco de encinos sujetos a vientos huracanados. El movimiento del árbol con el viento sobre árboles no podados fue comparado al movimiento de árboles con copas aclaradas, reducida o elevadas. Veintitrés árboles fueron azotados por el viento usando un generador arriba de $45 \mathrm{~m} / \mathrm{s}(110 \mathrm{mph})$, mantenido por tres minutos. Cada árbol fue instrumentado con sensores de orientación a diferentes alturas a los largo del tronco como una medida de su deflexión. El aclareo o reducción de la copa redujo significativamente el movimiento en la parte superior del tronco a todas las velocidades del viento, mientras que la elevación de copa no lo hizo. El movimiento de la parte baja del tronco no fue afectado por el tipo de poda. Estos datos indicaron que el follaje y las ramas hacia la parte alta de la copa del árbol fueron principalmente responsables del movimiento del tronco en línea directa con el viento con la parte baja menos importante. Los árboles que son reducidos o aclarados en la forma descrita podrían recibir menos daño con vientos de tormentas. 